\title{
Graphic Novel Collections in Academic ARL Libraries
}

\section{Cassie Wagner}

This study examines the extent to which ARL academic libraries collect graphic novels. Using a core list of 176 titles developed from winners of major comics industry awards and a library-focused "best of" list, the holdings of $111 \mathrm{ARL}$ academic libraries were searched using the libraries' online catalogs. Results suggest that most of the libraries studied do not aggressively collect graphic novels. Also examined were associations between date of publication, prior serialization, overall collection size, monograph budget, and $A R L$ ranking and graphic novel holdings. To better serve scholarly research in this area of increasing interest, libraries will need to reexamine their collecting policies.

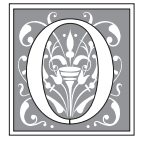

ne of a handful of art forms whose development began in the United States, comic strips appeared around the turn of the twentieth century. The first generally recognized comic book, Famous Funnies, appeared in 1934. The success of this work, a compendium of previously published newspaper comic strips, led other comic strip syndicates to create their own collections and quickly commission new material for the new format. The genre most commonly associated with comic books, superhero adventures, began in earnest with the first appearance of Superman in 1938. In that character's wake, a wave of superpowered heroes emerged, challenging the existing genres of romance, mystery, horror, and western comics. Public outcry over comics' supposed role in juvenile delinquency in the 1950s led to an extended slump in comics sales and creativity.
Comics have undergone a renaissance in recent years. Since the mid-1980s, an increasing number of comics have focused on stories that appeal to readers outside the stereotypical demographic of young men and boys. ${ }^{1}$ Comics imported from Japan-manga-and stories in genres other than superheroics and science fiction have appeared. This broader approach has reaped dividends. Trade comics and graphic novels are a fast-growing area of publishing, with sales topping $\$ 250$ million in 2005, more than triple the amount sold in 2001. ${ }^{2}$ In addition, a number of major recent movies based on comic books have succeeded at the box office. Movies such as Spider-Man, Road to Perdition, X-Men, Fantastic Four, Iron Man, and Watchmen demonstrate that the stories told in comics have an appeal and a relevance beyond the traditional format and audience.

Mirroring this popular appeal, comics have been receiving increasing critical

Cassie Wagner is Web Development Librarian in the Morris Library at Southern Illinois University Carbondale; e-mail: cwagner@lib.siu.edu. (C) Cassie Wagner 
and scholarly attention. Comics have won prestigious literary awards such as the Pulitzer Prize (Maus), American Book Award (Palestine), Hugo Award (Watchmen), and Guardian Prize (Jimmy Corrigan) and have been recognized as a best paperback of the year by Publishers Weekly (Kings in Disguise). ${ }^{3}$ The amount of scholarship on comics has increased continually since the 1960s as interest in all instruments of popular culture and media has increased. ${ }^{4}$ Michael Rhode and John Bullough's online bibliography of both popular and scholarly articles about comics and comic strips runs over 1,100 pages. $^{5}$

Like genre fiction, comics are a rich cultural text that provides insight into the period they were created. Issues tackled directly or implicitly in the stories reflect the issues and concerns of the times. Unlike genre novels, however, comic books contain images, giving shape to the ideas of the artists and authors. As a mass medium, comics reflect the ideas and symbols important to the culture at the time of their creation. ${ }^{6}$ They also provide evidence and interpretation of social change, as well as historical and current events. ${ }^{7}$ Like genre novels, comics are a medium that has influenced millions of lives over the years and, until recently, been largely ignored by scholars as a source of cultural information.

As documented by Ellis and Highsmith in their article, "About Face: Comic Books in Library Literature," libraries and librarians have often led the charge against comic books, perhaps to reinforce their self-image as protectors of art and knowledge. Over time, this attitude has slowly changed. ${ }^{8}$ Today, comics are regularly reviewed in publications for librarians (for instance, Library Journal, Booklist, Choice, and Voice of Youth Advocates). Diamond, the major distributor of comics in the United States, has devoted a section of its Web site and marketing energy to courting the library market. Twenty academic Association of Research Libraries members hold archival collections of comic books. In addition, several ARL member libraries have resource guides related to comic books and/or strips.

Terminology when talking about this medium can be confusing. What are comic books, trade comics, and graphic novels? What are the differences between them, if any? At a basic level, all are constructed in the same way, using a combination of images and text to tell a story. Comic books usually are magazines of 32 to 48 pages sold as serials. Trade comics are collections of the content of several comic books bound together and sold as monographs. Graphic novels are long works issued in a monograph without prior serialization. It is generally agreed by comic book scholars that the first true graphic novel published in the United States was Will Eisner's A Contract with God and Other Tenement Stories, which appeared in $1978 .{ }^{9}$

This study looks at both trade comics and graphic novels. The author uses the term "comics" to refer to materials in both categories. Of the titles examined, more than half were serialized in part or in their entirety prior to publication as monographs. Another large percentage was issued only as monographs. A very small number were initially published as longer single works and then combined to form larger monographs.

This study seeks to document the holdings of graphic novels in academic libraries. A further goal is to gauge library acceptance of comics, as well as the support given to research on this popular culture medium.

\section{Methods}

In general, this study follows the methodology used by Kevin P. Mulcahy in his "Science Fiction Collections in ARL Academic Libraries." ${ }^{10}$ Because of differences in the media examined, some alterations were necessary.

It was hypothesized that there would be a positive correlation between library holdings of graphic novels and the following variables: overall collection size, the 
library's monograph budget, the presence of an archival collection of comic books, and currency of book publication.

A list of core graphic novel titles was developed using a subset of winners of the Eisner and Harvey Awards. These awards function similarly to the Academy Awards for film, with awards granted in a variety of categories each year. Titles are nominated for awards by a panel of experts and then voted on by a large number of comics industry professionals. The categories chosen for this study best reflect the type of graphic novels collected by libraries because of their emphasis on book-length stories. The list of Eisner Award winners came from Wikipedia, and that of Harvey winners came from the award organizer's Web site. ${ }^{11}$

Because neither the Eisners nor Harveys extend back to the beginning of the medium, a list of valuable works that span the medium's history was also sought. Stephen Weiner's The 101 Best Graphic Novels is a well-recognized list of recommendations for libraries and was used to identify important graphic novels that have not won awards. ${ }^{12}$ In all, 176 titles were included.

ARL libraries were identified using ARL's Web site. Public libraries and research libraries not associated with a college or university were removed. Two francophone Canadian universities with French language catalogs were excluded. A total of 111 libraries were examined. ${ }^{13}$ This list does overlook several major collections of graphic novels and popular culture materials, such as that at Bowling Green State University, held by non-ARL libraries and nonacademic ARL members.

Libraries' holdings were determined through searches of the libraries' online catalogs. The searches were conducted between March and August 2007. Only books listed as being in the English language and available in circulating collections were included. Several of the schools examined have extensive collections of comic books, including some serial comic books that were later collected to form the selected titles. These serial comics were not included because they were not part of circulating collections. Noncirculating collections were excluded because of the difficulty in obtaining holdings information for some of these collections online. Books listed as available in the catalog at that time (not those on order or shown as missing) were counted. Titles available through a consortium or at branch campuses were not included.

Because many of the titles considered have complicated publishing histories,

\begin{tabular}{|c|c|c|}
\hline \multicolumn{3}{|c|}{$\begin{array}{c}\text { TABLE } 1 \\
\text { Comics Awards Included in Study }\end{array}$} \\
\hline Award & Abbreviation & Time Period \\
\hline 101 Best Graphic Novels & $\mathrm{W}$ & \\
\hline Eisner: Best Serialized Story & E1 & $1993+$ \\
\hline Eisner: Best Finite/Limited Series & E2 & $1988+$ \\
\hline Eisner: Best Graphic Album & E3 & 1988-1989 \\
\hline Eisner: Best Graphic Album New & E4 & $1991+$ \\
\hline Eisner: Best Graphic Album Reprint & E5 & $1991+$ \\
\hline Eisner: Best U.S. Edition of Foreign Material & E6 & $1998+$ \\
\hline Harvey: Best Graphic Album & $\mathrm{H} 1$ & $1988-1990$ \\
\hline Harvey: Best Graphic Album of Original Work & $\mathrm{H} 2$ & $1991+$ \\
\hline Harvey: Best Graphic Album of Previously Published Work & H3 & $1991+$ \\
\hline Harvey: Best American Edition of Foreign Material & H4 & $1988+$ \\
\hline
\end{tabular}




\begin{tabular}{|c|c|c|c|c|c|c|c|}
\hline \multicolumn{8}{|c|}{$\begin{array}{r}\text { TABLE } 2 \\
\text { Total Graphic Novel Holdings of A }\end{array}$} \\
\hline $\begin{array}{l}\text { Percentage of Titles } \\
\text { Owned }\end{array}$ & $\begin{array}{c}100 \%- \\
76 \%\end{array}$ & $\begin{array}{c}75 \%- \\
51 \%\end{array}$ & $\begin{array}{c}50 \%- \\
26 \%\end{array}$ & $\begin{array}{l}25 \%- \\
16 \%\end{array}$ & $\begin{array}{c}15 \%- \\
11 \%\end{array}$ & $\begin{array}{c}10 \%- \\
6 \%\end{array}$ & $\begin{array}{l}5 \%- \\
1 \%\end{array}$ \\
\hline Number of libraries & 1 & 4 & 21 & 20 & 22 & 30 & 13 \\
\hline $\begin{array}{l}\text { Percentage of } \\
\text { libraries in study }\end{array}$ & $1 \%$ & $4 \%$ & $19 \%$ & $18 \%$ & $20 \%$ & $27 \%$ & $12 \%$ \\
\hline
\end{tabular}

determining which books matched the award winners was challenging. Where possible, the exact edition that won the award was selected. Books that contained identical content (with the possible exception of introductions and afterwords) were included even if the titles were slightly different from the award-winning version. These difficulties may have caused some titles to be overlooked in the searches, although every effort was made to locate each title at each library. In fact, an early attempt to search using OCLC's WorldCat was abandoned because the sheer number of records for each title caused considerable confusion.

\section{Results}

Significant positive correlations were found between each of collection size $(\mathrm{r}=0.505)$, monograph budget $(\mathrm{r}=0.483)$, and ARL ranking $(\mathrm{r}=0.520)$ and comics holdings using the CORR procedure in SAS. Libraries with more books and larger budgets hold more graphic novels than libraries with smaller collections and smaller budgets. Large collection sizes and monograph budgets positively influence ARL rank. Several of the libraries studied support centers for the study of popular culture, including the two libraries with the greatest total holdings, Ohio State University and Michigan State University.
A list of academic ARL libraries with archival comics collections was developed by comparing the list of ARL libraries with the comics collections listed by Randall W. Scott. ${ }^{14}$ There was no significant difference between the holdings of libraries with and without archival comics collections $(P=0.047)$ as shown by the TTEST procedure. However, the mean number of titles (40.3) held by libraries with archival comics collections was lower (57.4) than that of libraries without such collections. This may be explained by these libraries holding the serialized versions of the titles searched. Also, some archival collections are based on one-time donations and may not reflect a continuing interest in collecting comics materials.

The graphic novels selected for this study were published between 1975 and 2006. The distribution of titles tends more heavily toward the recent period, as this is a relatively young and growing medium.

Graphic novels published in the most recent five years given (2002-2006) were no more likely to be held than graphic novels published earlier $(P=0.422)$. There was also no significant relationship in holdings between titles that were serialized first and those released initially as monographs $(P=0.472)$. Both relationships were calculated using the TTEST procedure.

\begin{tabular}{|c|c|c|c|c|c|c|}
\hline \multicolumn{7}{|c|}{$\begin{array}{c}\text { TABLE } 3 \\
\text { Distribution of Titles by Date of Publication }\end{array}$} \\
\hline Period & $\begin{array}{c}1975- \\
1984\end{array}$ & $\begin{array}{c}1985- \\
1989\end{array}$ & $\begin{array}{c}1990- \\
1994\end{array}$ & $\begin{array}{c}1995- \\
1999\end{array}$ & $\begin{array}{c}2000- \\
2004\end{array}$ & $\begin{array}{c}2005- \\
2006\end{array}$ \\
\hline Number of titles & 2 & 15 & 28 & 49 & 60 & 22 \\
\hline Percentage of titles in study & $1 \%$ & $9 \%$ & $16 \%$ & $28 \%$ & $34 \%$ & $13 \%$ \\
\hline
\end{tabular}




\begin{tabular}{|c|c|c|c|c|c|c|c|}
\hline \multicolumn{8}{|c|}{$\begin{array}{r}\text { TABLE } 4 \\
\text { Individual Graphic Novels Hel }\end{array}$} \\
\hline $\begin{array}{l}\text { Percentage of } \\
\text { Libraries Holding } \\
\text { the Title }\end{array}$ & $\begin{array}{c}100 \%- \\
76 \%\end{array}$ & $\begin{array}{l}75 \%- \\
51 \%\end{array}$ & $\begin{array}{l}50 \%- \\
26 \%\end{array}$ & $\begin{array}{l}25 \%- \\
16 \%\end{array}$ & $\begin{array}{c}15 \%- \\
11 \%\end{array}$ & $\begin{array}{c}10 \%- \\
6 \%\end{array}$ & $\begin{array}{c}5 \%- \\
1 \%\end{array}$ \\
\hline Number of titles & 3 & 8 & 31 & 35 & 16 & 28 & 54 \\
\hline $\begin{array}{l}\text { Percentage of titles } \\
\text { in study }\end{array}$ & $2 \%$ & $5 \%$ & $18 \%$ & $20 \%$ & $9 \%$ & $16 \%$ & $32 \%$ \\
\hline
\end{tabular}

\section{Discussion}

The results related to budget and collection size were not surprising. It is self-evident that libraries with large materials budgets will have large collections. As comic books are not often a primary collecting area, it seems logical that they will be acquired in quantity only by the richest libraries. Even then, the rate of acquisition will lag behind that for novels, even genre fiction novels. The case of Texas A\&M University is instructive. Ranked third by total holdings in both this study and in Mulcahy's examination of science fiction, Texas A\&M owns 84.5 percent of Mulcahy's list of 200 novels but only 65 percent of the 176 graphic novels selected for study here. ${ }^{15}$ At libraries with large or small budgets, graphic novels are of secondary (or tertiary) importance in collection building.

It is interesting that institutions with archival collections of serial comics do not hold more graphic novels than those libraries that do not. Perhaps this is because they do not want to spend limited budgets duplicating holdings. This practice, however, does limit usage of the collections by locking the comics away from the main stacks and imposing other restrictions on access, actions that frustrate many potential users.

The lack of difference in holdings between stories that were originally released serially and those initially issued as graphic novel is illustrative of several things. First, it seems that quality books are recognized by academic libraries regardless of their original publication date, which is in line with the mission of such libraries as repositories for knowledge across time. Second, it seems likely that many of these collections were created recently from the ground up, as opposed to slowly accumulating over a long period of time. This trends against a time differential, as librarians would choose titles from what was available regardless of its date of creation.

Another detail that emerged from this study relates to author demographics. The authors of the selected graphic novels are overwhelmingly American, male, and white. The prevalence of Americans is likely a reflection of using American awards and a list of titles generated by an American librarian. That they are male and white is a reflection of an industry-described by some women working within it as an "old boys' club" - that has long been considered unfriendly to women and people of color. ${ }^{16}$ In fact, only six women appear as authors of books on the list. Only four appear as artists (and each of those draws a story she wrote). The largest group of people of color is Japanese, a reflection of the presence of a number of manga (Japanese comics) titles on the list. These authors, too, are overwhelmingly male. Thankfully, the female role in comic book creation is growing as the format gains sales and respect.

Overall, collections of graphic novels in ARL libraries are limited. This is shown clearly in that nearly one-third (32\%) of the selected titles are held by between 5 percent and 1 percent of ARL libraries. Only 2 percent of titles are held by more than three-quarters of ARL libraries. These collections of graphic novels are often limited to a handful of titles, often lacking the depth and breadth of holdings for comparative studies. 


\section{Opportunities for Further Research}

This study raises issues for future exploration. All of the titles on this list were selected by experts. It would be enlightening to examine what comic books enthusiasts think are the most useful titles, perhaps by comparing sales figures or the results of the awards voted on by readers, such as those of Wizard magazine, to academic library holdings. An attempt could also be made to locate and include books that provide a greater diversity of voices by adding more works by women and people of color. Many comics feature stories that span several bound volumes. A further study could examine whether academic libraries hold the entire series and why they do or do not. Finally, a study could be conducted to examine how comics are cataloged and shelved in academic libraries: whether they are shelved together under the heading for comics, shelved under their content's subject, or kept in a recreational reading area. Such a study could provide further insight into academic libraries' attitudes toward the medium.

\section{Conclusion}

Academic ARL library graphic novel collections lag behind those of another media long neglected by academic libraries: science fiction novels. As documented by Mulcahy, the most commonly held science fiction novel (Kurt Vonnegut's Slaughterhouse Five) is found in 99 per- cent of academic ARL libraries. The library holding the most science fiction novels on Mulcahy's list owns 97 percent of all titles. ${ }^{17}$ In comparison, the graphic novel held most commonly (Art Spiegelman's Maus) is found in 93 percent of libraries, and the largest holdings are those of a library owning 78 percent of the titles on the list. While some graphic novel titles have obvious been widely adopted by academic libraries, the majority of them continue to be overlooked.

Comics are a vital and growing medium with importance to scholars investigating both popular culture and culture in a larger sense. They are a reflection of popular thought and concerns and a tangible representation of a contemporary culture that is both increasingly visually oriented and electronically based. Some comics titles can provide an unbroken narrative line stretching back almost 70 years. These useful materials are increasingly collected by academic libraries. Even so, the rate of collection lags behind that for other popular culture materials, such as science fiction novels. ${ }^{18} \mathrm{~A}$ handful of titles are widely collected by ARL libraries and a handful of ARL libraries collect a large number of comics. It would be useful for more academic libraries to incorporate comics into their collections to better support and foster research on this important art form and cultural artifact.

\section{Notes}

1. Stephen Weiner, Faster Than a Speeding Bullet: The Rise of the Graphic Novel (New York: NBM, 2003), xi.

2. Associated Press, "As More Graphic Novels Appear in Libraries, So Do Challenges" (Nov. 24, 2006). Available online at www.firstamendmentcenter.org/news.aspx?id=17805. [Accessed 20 March 2008].

3. Weiner, Faster Than a Speeding Bullet, xi, 51, 54, 58; Hugo Awards Marketing Subcommittee of the World Science Fiction Society Mark Protection Committee, "Hugo Award History" (2007). Available online at www.thehugoawards.org/?page_id=6. [Accessed 30 April 2007].

4. Allen Ellis and Doug Highsmith, "About Face: Comic Books in Library Literature," Serials Review 26, no. 2 (2000): 39.

5. Michael Rhode and John Bullough, Comic Research Bibliography (Dec. 2007). Available online at www.rpi.edu/\%7Ebulloj/comxbib.html. [Accessed 20 March 2008].

6. M. Thomas Inge, "Introduction to 'The Comics as Culture'," The Journal of Popular Culture 12, no. 4 (1979): 631.

7. Leslie Bussert, “Comic Books and Graphic Novels: Digital Resources for an Evolving Form 
of Art and Literature," CERL News 66, no. 2 (Feb. 2005): 103.

8. Ellis and Highsmith, "About Face," 30.

9. Will Eisner, A Contract with God and Other Tenement Stories (New York: Baronet, 1978).

10. Kevin P. Mulcahy, "Science Fiction Collections in ARL Academic Libraries," College and Research Libraries 67, no. 1 (2006): 16-18.

11. "Eisner Award-Wikipedia, the Free Encyclopedia" (2007), available online at http:// en.wikipedia.org/wiki/Eisner_Award [Accessed 30 April 2007]; “The Harvey Awards" (2007), available online at www.harveyawards.org/awards_current.html [Accessed 30 April 2007].

12. Stephen Weiner, The 101 Best Graphic Novels (New York: NBM, 2005).

13. "Association of Research Libraries: Member Libraries" (2007). Available online at www.arl. org/arl/membership/members.shtml [Accessed 30 April 2007]. The two francophone universities excluded were Université de Montréal and Université Laval.

14. Randall W. Scott, Comics Research Libraries (Feb. 24, 2005). Available online at www.lib. msu.edu/comics/director/comres.htm. [Accessed 5 March 2008].

15. Mulcahy, "Science Fiction Collections," 20.

16. Trina Robbins, From Girls to Grrrlz: A History of Women's Comics from Teens to Zines (San Francisco: Chronicle Books, 1999), 85.

17. Mulcahy, "Science Fiction Collections," 20, 24.

18. Ibid., 24-29.
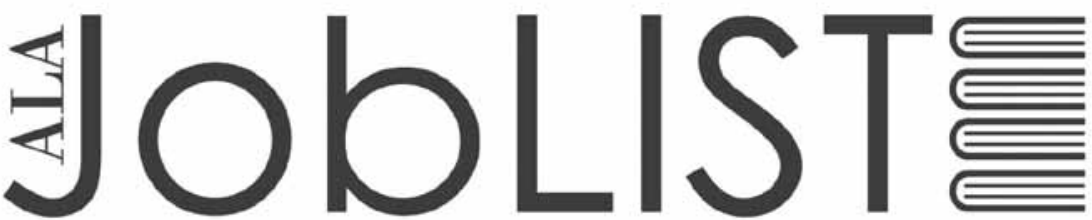

The \#1 source for jobs in Library and Information Science and Technology

\section{WHERE JOB SEEKERS AND EMPLOYERS GET RESULTS}

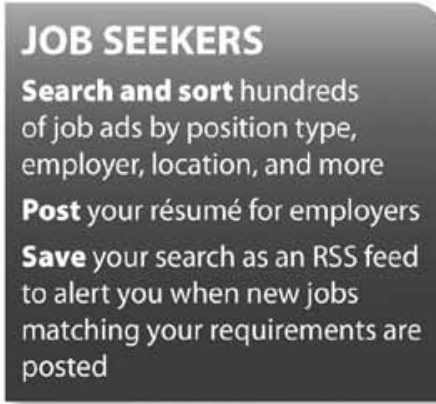

\section{EMPLOYERS}

Strengthen your candidate pool-

$A L A$ reaches the most engaged

professionals and students

Simplify recruitment-one-stop advertising for online and print

Review posted résumés

Connect with candidates

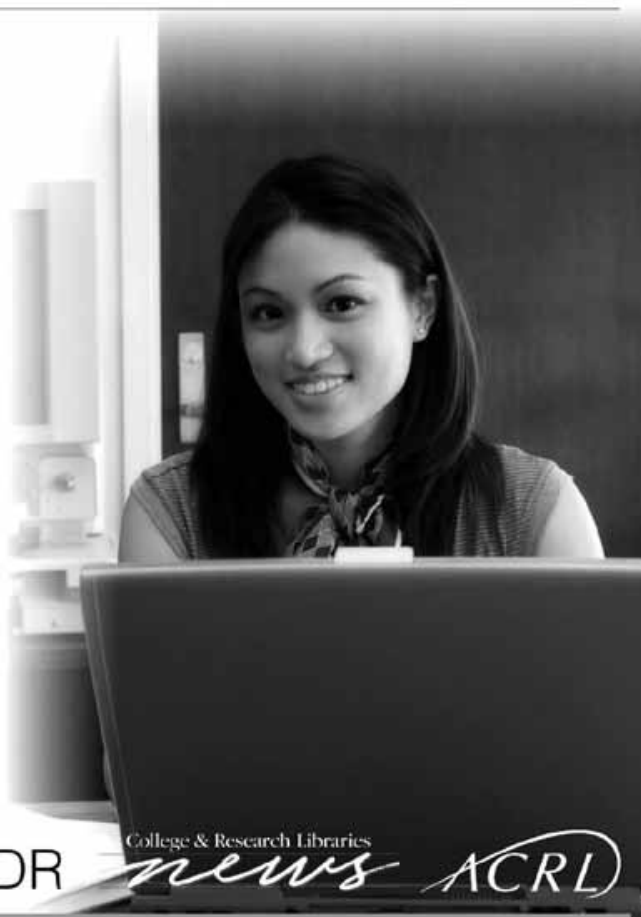

joblist.ala.org 